\title{
Examining the Effectiveness of Microfinance Institutions' Services on Women Economic Empowerment in Tanzania, Case of BRAC Tanzania
}

\author{
Ester Alleluya Mwakisaje \\ Shanghai university, 20044 Shanghai China. \\ Evetha Kisanga \\ ST Augustine University of Tanzania, 307 Mwanza, Tanzania
}

\begin{abstract}
Microfinance is the provision of thrift credit and other financial services and products of the very small amount to the rural, semi-urban or urban areas for enabling them to raise their income levels and improve their living standard. (Joshi, 2006). The present study aimed to examine the effectiveness of microfinance institutions' services on women economic empowerment in Tanzania. Primary data were collected by researchers by interviewing 200 female customers taking credit from BRAC (Arusha branch). Questionnaires were filled by 10 BRAC staff and management. The findings show that among the women interviewed, they benefit from 60 percent of their loans in doing business startup, 20 percent in gaining respect in the community, 10 percent in feeding the family, 8 percent in educating the family while 2 percent in covering the medical expenses. Generally majority of women tend to benefit from their loans in terms of starting their own business as they use the largest part of their loans in creating and establishing their own businesses.
\end{abstract}

Keywords: microfinance, microfinance institutions, women economic empowerment, loans, BRAC

DOI: $10.7176 / \mathrm{RJFA} / 12-4-03$

Publication date: February $28^{\text {th }} 2021$

\subsection{Introduction}

Empowerment of is a global challenge since traditionally women have been marginalized and subjected under the control of men. About 70 percent of the world's poor are women (Khan and Noreen, 2012). Thus this has necessitated the implementation of women empowerment all over the world. Empowerment of women through small and medium enterprises is affected through increasing their access to financial services such as credit training in entrepreneurship, training in business management and access to market (Mgossi, 2011).

The government of Tanzania through National Microfinance policy has issued guidelines to achieve gender equity in accessing financial services, but the policy similarly provides ample flexibility in microfinance institutions in making services accessible to both women and men on the terms and conditions they can afford. Moreover, efforts are being engaged by the government of Tanzania to acquire standard and increase access to both local and foreign markets (Mgossi, 2011). In 2001 the National microfinance policy was introduced for the purpose of poverty alleviation and women empowerment. Currently women are the major beneficiaries of microfinance institutions as they constitute ninety-five percent of all microfinance borrowers (Armendariz 2005).

The concept of microfinance institutions can be traced back to Mohammad Yunus who developed it as a way to eradicate poverty in his home in Bangladeshi. In 1983, he founded Grameen Bank, the first institution to operate in microfinance business in proper sense. Yunus and Grameen Bank were laureates of the 2006 Nobel peace prize awarded for their efforts through micro credit to create economic and social development from below (Yuqing C, 2006).

In Tanzania, the history of microfinance starts way back in 1985 where the government promoted and established the Presidential Trust Fund (PTF) in mid 1990s to offer microfinance services. Other Microfinance institutions emerged such as Promotion of Rural Initiative and Development Techniques (PRIDE), Foundation of International Community Assistance (FINCA) and Youth Self Employed Foundation (YOSEFO). In late 1990's the bank of Tanzania started specialized banks which are commonly known as community banks and cooperative banks. These include Kilimanjaro Cooperative Bank, Akiba Commercial Bank, Mufindi Community Bank Limited and Kagera Cooperative Bank Limited. Akiba Commercial Bank became the first one to venture into microfinance (Tanzania Association of Microfinance Institution, 2016).

Microfinance through financial services tailored for poor people, has been celebrated for its ability to reach out to women and enhance their welfare (Mersland R, 2009). The argument behind MFIs targeting women is that putting resources into poor women's hands while promotion gender equality in the household and in society results in large development payoffs. Expanding women's opportunities in public works, agriculture, finance, and other accelerate economic growth helping to mitigate the effects of current and future financial crises.

Female clients represent ninety-five percent of the poorest microfinance clients reached. Therefore, targeting 
women borrowers makes sense from a public policy standpoint. The business case for focusing on female clients is substantial, as women clients register higher repayment rates. They also contributed larger portions of their income to household consumption than their male counterparts. There is thus a strong business and public policy case for targeting female borrowers (World Bank, 2011).

\subsection{Brac Microfinance}

BRAC, an international development organization based in Bangladesh, is the largest non-governmental development organization in the world, in terms of number of employees as of June 2015. Established by Sir Fazle Hasan Abed in 1972 after the independence of Bangladesh, BRAC is present in all 64 districts of Bangladesh as well as other countries in Asia, Africa, and the Americas.

BRAC employs over 100,000 people, roughly 70 percent of who are women, reaching more than 126 million people The organization is $70-80 \%$ self-funded through a number of commercial enterprises that include a dairy and food project and a chain of retail handicraft stores called Aarong. BRAC maintains offices in 14 countries throughout the world, including BRAC USA and BRAC UK.

BRAC considers itself to have a unique philosophy towards eradicating poverty. As one author has said, "BRAC's idea was simple yet radical bring together the poorest people in the poorest countries and teach them to read, think for themselves, pool their resources, and start their own businesses Sir Fazle Hasan Abed strongly believed that poverty alleviation could be achieved only through an improvement to multiple issues plaguing a country, which explains the vast range of programs that BRAC is involved in. Furthermore, his conviction that poverty amelioration could only be sustained through greater equality in gender roles led BRAC to heavily advocate women's rights and the improvement of women's welfare.

BRAC started its work in Tanzania in 2006 by adapting and implementing its comprehensive development models reaching approximately 2.64 million people, with programmes in microfinance, small enterprises development, education, agriculture, poultry and livestock and empowerment and livelihood for adolescent.

\subsection{LITERATURE REVIEW}

\section{Empirical literature}

According to Sutton-Brown (2011) conducted a research titled Women Empowerment in the context of Microfinance: A photo voice study. The purpose of the study was to explore how a selected group of women perceived and experienced empowerment in relation to their participation in a microfinance program. The researcher used qualitative research which covered West Africa women specifically is Mali. The findings of the study indicate that microfinance has positively and negatively impacted various dimension of women's perceived empowerment.

Sutton-Brown concluded that women participate is a forum and initiated policy changes at the microfinance institutions with which they are affiliated.

From the study above indicated that women perceived that microfinance can attract negatively or positively on empowerment of Mali women. However, in this study the researcher is aimed at examining the effectiveness microfinance institutions services on women economic empowerment in Tanzania using BRAC as a case study.

Major and Manders (2009) conducted a research titled Women's Empowerment; Comparing concept \& Assessing Implication for Microfinance. The study aimed at assessing what is the difference between the concept of women empowerment in North and South, what aspect of women's empowerment are mostly important to clients of the MFI project partners and how microfinance contributes to the empowerment of women. The researchers used both qualitative and quantitative approach where by targeted four countries from four difference continents which are Bulgaria, Kenya, Peru and Philippines. The researcher concluded that there was no big deference in the meaning of women empowerment from North and South, however from this study the researcher aims at examining the effectiveness of microfinance institutions services on women economic empowerment in Tanzania using BRAC as a case study.

Kato and Kratzer (2013) conducted a research titled Empowering Women through Microfinance: Evidence from Tanzania. In dealing with the research the researchers used both qualitative and quantitative methods. The targeted population was three regions and a sample size of 454 women (305 members of MFIs and 149 nonmembers) of MFIs. The findings show that there is a significant difference between the women members of MFIs and non-members in dependent variables related to women empowerment. Researchers concluded that women members of MFIs have more control over savings and income generated from the business, greater role in decision making, greater self-efficiency and self-esteem and greater freedom of mobility and increased activities outside home.

From above, the researchers concluded that here is a difference in the level of empowerment among the MFIs members and those non-members. However, this study aimed at examining the effectiveness of MFIs' services on women economic empowerment in Tanzania using BRAC as a case study. 


\subsection{Conceptual framework model}

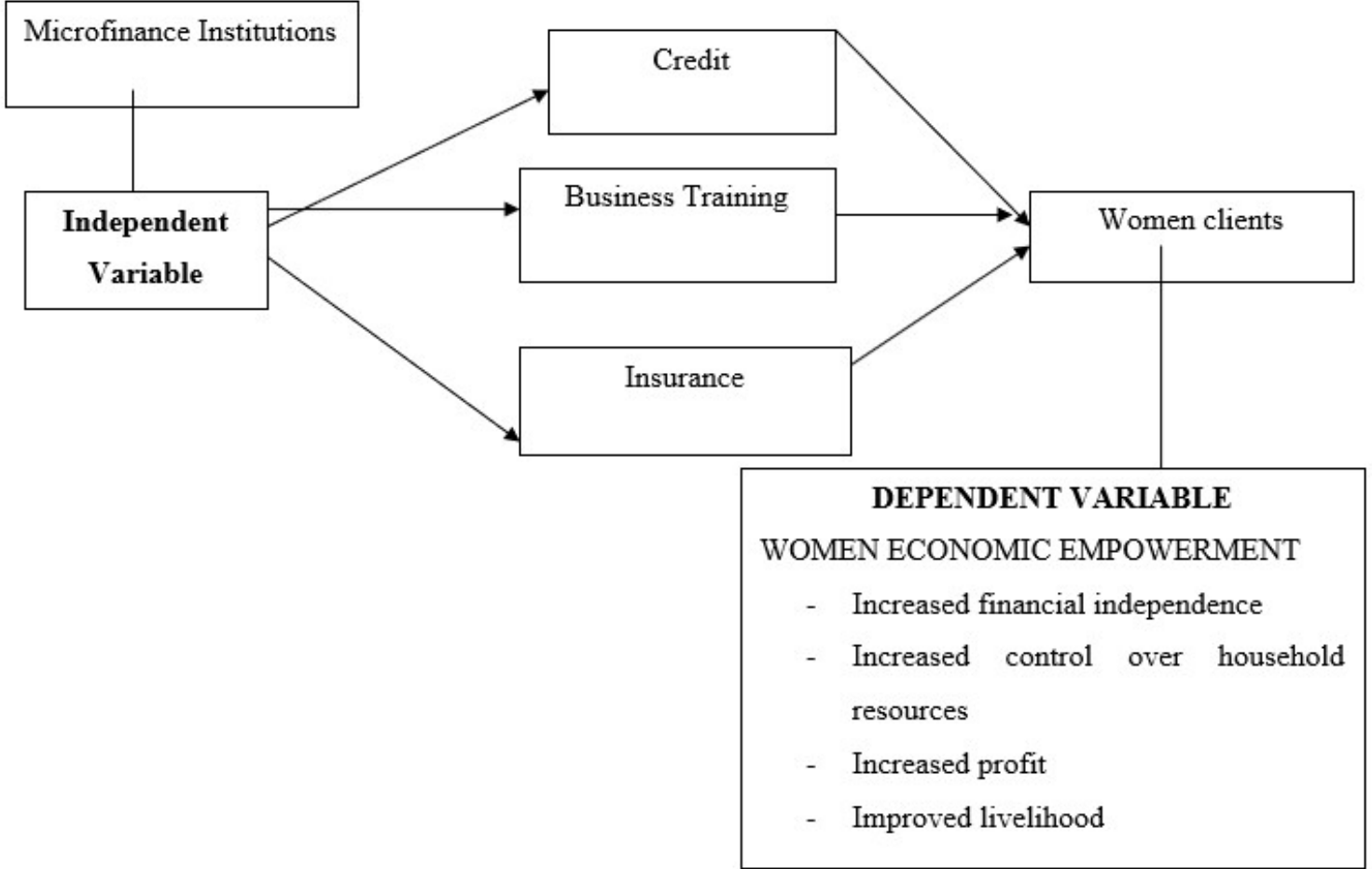

Source: Researchers.

When credits are provided to people, they may very well be able to start or expand a micro-enterprise that will allow them to break out of poverty. Microcredit is largely use as a means of boosting income of people (Paulson and Townsend, 2004). These loans are an effective way for the poor to eradicate poverty. It works for the well-being of the poor, improve the earning capacity.

Therefore improve the living standard for the poor. Credits also empower women by enabling the $\mathrm{m}$ to take economic decisions.

Nhung Thi Hong et al (2015) concluded that business training leads to significant improvements in business knowledge of participating women. The training is found to positively impact business performance of female-run businesses leading to increase in profit margins. This is because business training aims at enhancing the business management skills by increasing business knowledge that will help women implement new business practices that will lead to an improved business outcome.

Insurance reduces the vulnerability that women face. Women's physical vulnerability makes their property particularly vulnerable to theft and crime. Women are more susceptible to certain diseases, including AIDS and complications of pregnancy and childbirth. Women's responsibility to care for the sick means the ill health of their children and partner affects their own ability to earn. MFIs have developed micro insurance to address various sources of vulnerability. These products include compulsory insurance against loan defaults, health, life, livestock and property (IFAD, 2009).

\subsection{METHODOLOGY}

Data.

This researcher involved both primary data and secondary data. Primary data were collected by researcher by interviewing 200 female customers taking credit from BRAC (Arusha branch). Questionnaires were filled by 10 BRAC staff and management because of their ability to administer the questionnaire. But secondary data were collected by reading reports concerning credits offered to women by BRAC Tanzania and also the journals relating to microfinance and women empowerment were also reviewed by the researcher

The type of study was qualitative because the researcher intended to examine the effectiveness of microfinance institutions' services on women economic empowerment rather than to make predictions. We were able to gain an understanding on women's perception of economic empowerment through microfinance institutions services. Qualitative research state that theory is supposed to be an outcome of an investigation rather than something that precedes it (Bryman, 2008). 


\subsection{FINDINGS}

\section{Ways of loans provision to women}

One of the specific objectives of this study was to establish the ways to which BRAC provides loans to the women clients. In finding the answers to this objective, the researcher asked the women clients about the ways they use to secure their loans from the BRAC. Figure 3 below represents the answers to this question;

\section{Figure 1: Distribution of loan securing ways}

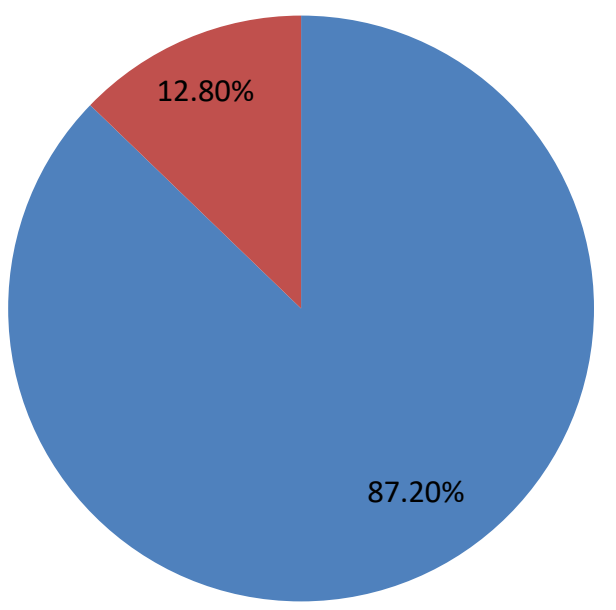

- Group lending

- Individual lending

Loans are secured using two approaches as shown above from the pie chart. The results show that 87.2 percent of women clients secure their loans in groups while 12.8 percent of women clients secure their loans individually. This means that the largest proportion of women secure loan in groups. It was generally found that one of the requirements for securing loans from BRAC is for the clients to present themselves in groups. This is done in order to ensure that loans are secured as women clients are likely to share the non-repayment risk and therefore better repayment is ensured and so does the minimal risk of loan default by the women clients. These results are in support of Godquin (2004) who finds that group lending helps to mitigate the default risk as women tend to share the loan liability.

\section{Loan repayment record.}

In order to establish the loan repayment status of the women clients, the women clients were asked about their ability to repay the loans on time and likely the staffs were asked to give their opinions regarding the women repayment records. The results were obtained and presented in the figure 4 below as follows;

\section{Figure2: Distribution of loan repayment record}

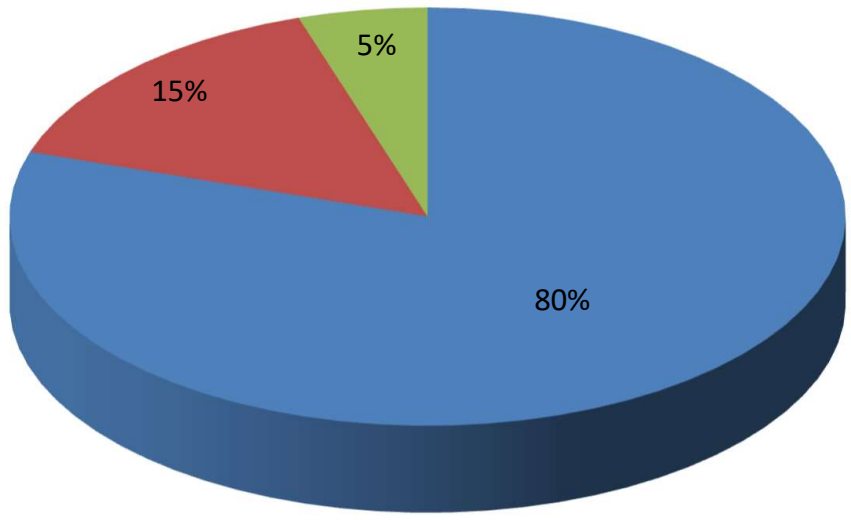

Pay on time

- Delay

Default

The research findings shows that 80 percent of women clients tend to repay their loans on time while the 
remaining 15 percent of women clients pay their loans late and 5 percent of women tend to default. Generally the largest proportion of women tends to repay the loan on time. Women clients said that their ability to repay their loans on time mostly depends upon the performance of their businesses while those that delay and default is because of the poor performance of their businesses. These findings are in support of the World Bank (2011) who finds that women tend to register higher repayment rates.

\section{Loan repayment period}

The researcher intended to establish the duration taken by the women clients to repay their loans. The researcher therefore asked the respondents on the repayment period offered to them by the BRAC organization. The results were obtained and presented below as follows;

\section{Figure 3: Distribution of loan repayment period}

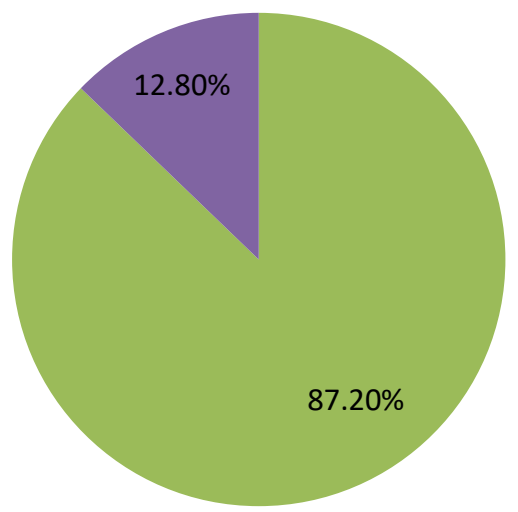

- Weekly

- Monthly

The research data reveals that 87.2 percent of women clients pay their loans liability on weekly basis while 12.8 percent of women pay their loans liability on monthly basis. The results show that the majority of women secure the loans on weekly basis. This is in support of Pereira and Mourao (2012) who stated that weekly payment is engaged so as to protect women from huge cash outflow and also frequent repayment provides a client with a commitment device that helps them form a habit of lending saving hence loan repayment.

\section{The role of credits on women economic empowerment}

In order to establish the role played by BRAC credits on women economic empowerment, women clients were asked if they benefit from the loans through women economic empowerment. The responses were obtained and presented below as follows;

\section{Figure 4: Distribution of role of credit on women economic empowerment}

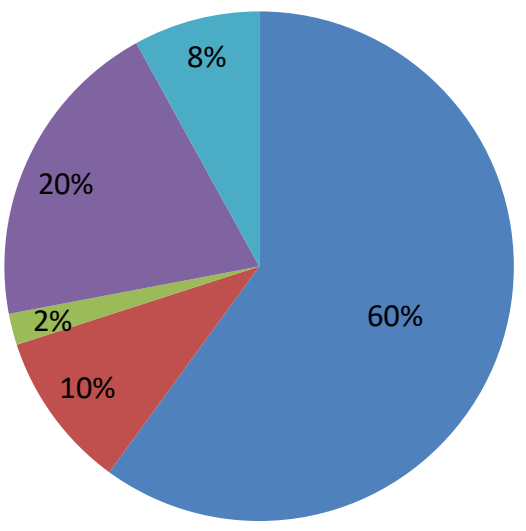

Business startup

Feeding the family

Medical expenses

Respected in the community

The findings show that among the women interviewed, they benefit from 60 percent of their loans in doing business startup, 20 percent in gaining respect in the community, 10 percent in feeding the family, 8 percent in 
educating the family while 2 percent in covering the medical expenses. Generally majority of women tend to benefit from their loans in terms of starting their own business as they use the largest part of their loans in creating and establishing their own businesses. The findings are in support of Kato and Kratzer (2013) who concluded that women have more control over savings and income generated from their businesses.

\section{Source of business capital}

Seeing that most women were able to start their own business, the researcher then asked the respondents as to what was the source of their business capital. The responses were obtained and presented as follows;

Table 1: Showing the source of business capital

\begin{tabular}{|l|l|l|l|l|}
\hline Source of capital & Frequency & Percentage & Valid percentage & Cumulative percentage \\
\hline Loan from BRAC & 46 & 76.7 & 76.7 & 76.7 \\
\hline Own savings & 14 & 23.3 & 23.3 & 100.00 \\
\hline Inheritance & 0 & 0 & 0 & 100.00 \\
\hline Total & 60 & 100 & 100 & 100.00 \\
\hline
\end{tabular}

The research data reveals that 76.7 percent of women clients' source of business capital was the loan from BRAC, while 23.3 percent of women clients' sources of business capital are the personal savings in addition to the loans from BRAC. So no one is getting anything from inheritance since this is a paternal society. The results are in support of Hunt and Kasynathian (2011) who found out that through microfinance loans women are now capable of doing business on their own and making decision and choices in their families.

The impact of loan on profit generation

In order to establish the role of the loan offered by BRAC on the profit generating activities of the women clients, the researcher asked the respondents if the loans secured by them have helped to increase the profit margin of their businesses. The following are the responses obtained as presented below;

Figure 5: Distribution of impact of loan on profit maximization

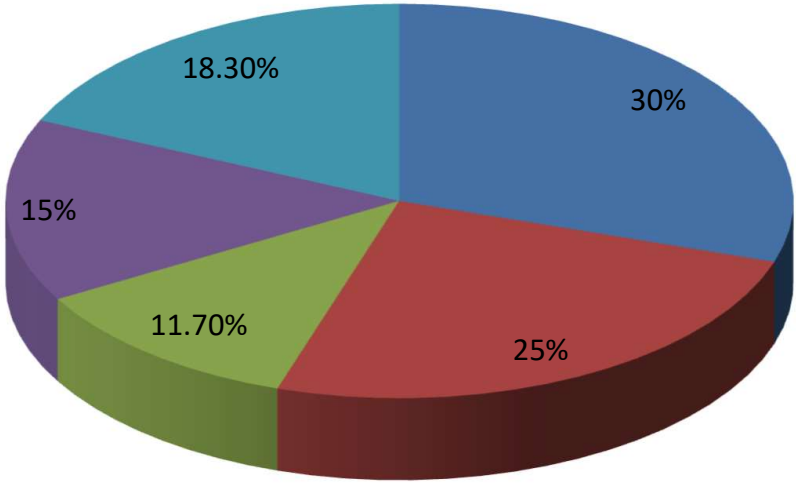

Increase in customers

Increase in goods

Hiring of people in their businesses

Creation of other business

Better services

The research data reveals that BRAC loan have been of good help to women since 30 percent of women have experience an increase in customers, 25 percent of women have experienced an increase in goods, 18.3 percent of women offers better services and 15 percent of women have created of other business and hiring of other people in their businesses. Generally, the results show that majority of women have experienced an increase in customers as a result of loan in their businesses. 
Figure 6 below shows the responses of the question as to whether women welfare and their family in general improved as a result of loan.

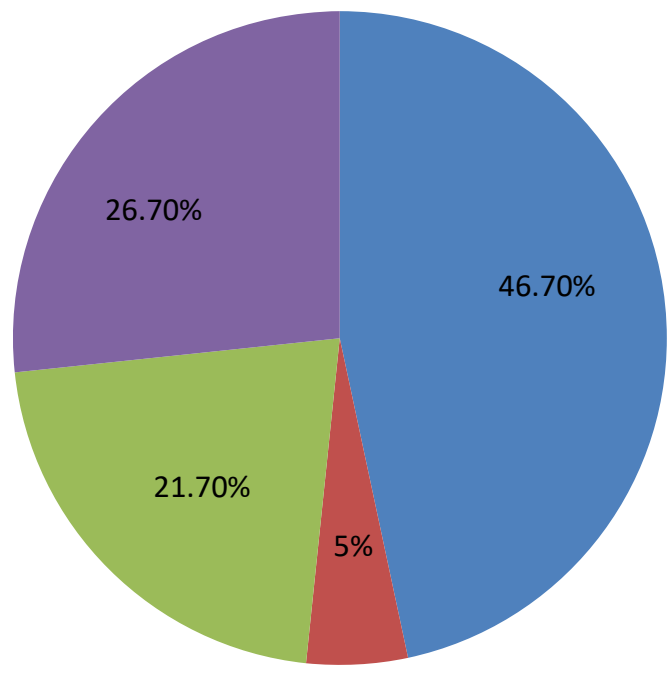

Business growth

- Own a house

Family welfare impovement

Respected in the community

The research findings have shown that women benefit from loans from BRAC. In this figure 46.7 percent of women claimed that their business grow as a result of loan secured from BRAC. About 21.7 percent of women say that their family welfare has improved. Likely 21.7 percent of women even claimed that their status quo in the community has been elevated to the community due to the fact that now they can afford a lot of items that they could not do that before secured a loan and 5 percent of women claimed that they own houses. The results are in support of Noreen (2011) who finds that loans used by women results to better outcomes.

Limitations women face when obtaining loans from BRAC

The researcher under this case intended to find out the limitations faced by women when obtaining loan from BRAC. The researcher therefore asked the respondents on the challenges they face when obtaining loans from BRAC.

Table 2: below shows the responses of the respondents;

\begin{tabular}{|l|l|l|l|l|}
\hline Limitation & Frequency & Percentage & Valid percentage & Cumulative frequency \\
\hline Lack of collateral & 32 & 53.3 & 53.3 & 53.3 \\
\hline Required guarantor & 9 & 15.0 & 15.0 & 68.3 \\
\hline Identity card & 6 & 6.0 & 6.0 & 74.3 \\
\hline Business license & 13 & 21.7 & 21.7 & 100.00 \\
\hline Total & 60 & 100 & 100 & \\
\hline
\end{tabular}

The research findings shows when obtaining loan from BRAC 53.3 percent of women lacked sufficient collateral such as title deed, 15 percent of women lacked guarantor, 6 percent of women lacked identity cards while 21.7 percent of women clients said they lacked business license when securing loan from BRAC. This is supported by IFAD (2006) who stated that there are challenges faced by microfinance institutions in offering services to their customers.

\section{Satisfaction rating from BRAC services}

The researcher aimed at establishing the degree of women satisfaction from the BRAC services. The researcher therefore asked the respondents as to whether they were satisfied with the services offered to them by BRAC. The responses were obtained and presented below as follows;

\section{Table 3: showing satisfaction rating from BRAC services}

\begin{tabular}{|l|l|l|l|l|}
\hline Satisfaction level & Frequency & Percentage & Valid percentage & Cumulative frequency \\
\hline A bit satisfied & 9 & 15.0 & 15.0 & 15.0 \\
\hline Satisfied & 28 & 46.7 & 46.7 & 61.7 \\
\hline Very satisfied & 23 & 38.3 & 38.3 & 100.0 \\
\hline Total & 60 & 100.0 & 100.0 & \\
\hline
\end{tabular}


The research findings show that 15 percent of women are a bit satisfied with the services offered by BRAC while 46.7 percent of women are satisfied with the services and 38.3 percent of women are very satisfied with the services offered to them by BRAC.

\subsection{SUMMARY AND CONCLUSION.}

The study has revealed that women are able to start their own business, educate their children, gain respect in the community, feed the family and also get medical attention through the financial services. This has then helped women to be self-independent financially without depending on their husband for the support. This is in support of Kato and Kratzer (2013) who concluded that women have more control over savings and income generated from business, greater role in decision making through the microfinance services

Also most women's source of business capital is the BRAC loan while some of them are from personal savings. The study has then shown that BRAC loan is a backbone to women economic empowerment as due to presence of BRAC women now own businesses. The loan received from BRAC has played a greater role in profit maximization as women have got more customers; they offer better services and also have increased goods in the business area and likely their families' standard of life has improved. This is supported by Rose (2004) who found out women own assets including land and house through financial services.

Women's welfare and that of their families has improved as well. This is because women have become more financially independent and do not depend on their husbands in matters concerning themselves and that of the families as since they play equal role in the family development.

Despite some limitations that women face when obtaining loan from BRAC, they perceive BRAC as a good organization that is more concerned with women's welfare. One of the respondents said "I so much appreciate the existence of BRAC in Tanzania as their presence has helped me as a woman since I have benefited a lot from the loan they offer to me. I pray that it never ceases to support us women; I can now take care of myself and my family all thanks to BRAC",

\subsection{RECOMMENDATIONS}

The government should initiate the public financial services in a sense that it encourages the microfinance institutions to offer the financial services in less strict terms. Likely the government should offer credits to women so as to ensure women economic empowerment is achieved. Also BRAC should provide business training to women on how they should run their business in order to ensure that they maximize their profit and hence pay their loan on time. They should also educate the women clients on the importance of loans to women in ensuring economical sustainability and how they should manage their cash. The entrepreneurial education should be provided to women so as to be well equipped with entrepreneurial skills. Budgeting lessons should be offered to women on how to budget and how to stick on their budget as well and also they should be taught on how to prepare a good business plan. Grace period should be extended so as to enable all women to pay their loans without delaying so as to ensure effective performance of BRAC functions. Interest rate should be lowered so as to enable each woman to participate in obtaining fund from BRAC as it is more focused on the welfare of women.

In this study we suggests that women should make good use of their money in running a profitable business so as to be able to pay their loans on time and not only that but also support themselves and their family as well since empowering women means empowering the whole society. Lastly the researcher identified an area to be researched which is how microfinance institutions benefit from the role it plays on women economic empowerment.

\section{REFERENCES:}

Alsop, R \& Heinsohn, N (2005) Measuring Empowerment in Practice: Structure Analysis \& Framing Indicators, WB Policy Research Working Paper.

Amendariz de Aghion, Beatriz \& Murdoch, Jonathan, (2005). The Economics of Microfinance, MIT Press, Cambridge, Mass

Bryman, A. (2008) Social Research Methods, $3^{\text {rd }}$ edition, New York; Oxford University Press.

Godquin, M. (2004) Microfinance Repayment Performance in Bangladesh; how to improve the allocation of loans by microfinance institutions. World Development, 32(11)

Hunt, J \& Kasynathan, N (2002) Reflections on Microfinance and Women Empowerment. Development Bulletin No 57

Joshi, D (2006) Social Banking-Promise, Performance \& Potential. Delhi Foundation

Kabeer, N. (2005) Is Microfinance a "Magic Bullet" for Women Empowerment Analysis of findings from South Asia. Economic and Political weekly http://go.worldbank.org.com retrieved on Tuesday $14^{\text {th }}$ at 12:36

Khan, L \& Cheston, S. (2002) Empowering Women through Microfinance, Draft Publication, sponsored by UNIFEM

Khan,KA. \& Rahman, A. (2007). Why do VO Members Drop out? BRAC, Dhaka 
Krishna A. (2012) Social Capital, Community Driven Development and Empowerment, A short not on concepts and operations; Word Bank Working Paper, WB, Washington, DC

Katherine N. R. Social Capital, Microfinance and Politics of Development, Rutledge Taylor \& Francis Group, Feminists Economics 8(1), $20021-24$

Kato M.P and Kratzer J (2013), Empowering Women through Microfinance: Evidence from Tanzania Journal of Entrepreneurship Perspective Vol 2. Issue 1 Page 31 - 59

Madajwicz, (2011). Individual lending Versus Group lending; An Evaluation of Kenya Microfinance data

Majour H \& Manders J (2009) Women Empowerment: Comparing Concepts and Assessing Implications for Microfinance, State of micro edit Summit Campaign Report

Malhotra et al (2002) Measuring Women's Empowerment on a variable in International Development Group. World Bank

Morduch, J and Haley, B (2001) Analysis of Effects of Microfinance on Poverty Reduction

Nader, Y.F, (2008) Microcredit \& Social economic well-being of women and their families in Cairo. Journal of Socio-Economic

Noreen, S. (2011) Role of Microfinance in Empowerment of Women Population of Bahawalpur District; Department of Economics Bahawalpur, Pakistan. International Conference on Economics \& Finance. Research

Nhung Thi Hong et al (2015) The impact of gender and business training for female microfinance clients

Ojo, O (2009) Impact of Microfinance on Entrepreneurial Development in Nigeria, the International Conference on Economics Administration, FAA, Burcharist

Pereira, S \& Mourao, P. (2012) Why does the Microcredit borrowing rate differ across countries? A cross country study

Rose, A. (2004). The Impact of Microfinance on the Empowerment of Rural Women

Sarumathi S and Mohan K. (2011) Role of Microfinance on Women empowerment, Journal of Management Science, Vol No 1

Swain, R \&Wallentin, F (2007) Does Microfinance Empower Women? Evidence from Self Help Groups in India, Department of Economics, Working paper, Uppsala University, Sweden

Sutton-Brown C.A (2011) Women's empowerment in the context of Microfinance. A photo voice study. U.S.A Congo State University.

United Republic of Tanzania (URT), (2005) Report on Implementation of Beijing Platform for action and outcome document. 